\title{
Life Cycle Assessment of Food Processing Systems in Toba Samosir Regency
}

\author{
Asido Situmorang ${ }^{1}$ and Yosef Manik $^{1 *}$ \\ ${ }^{1}$ Engineering Management Study Program, Faculty of Industrial Technology, Institut Teknologi Del, Laguboti 22381, \\ North Sumatera, Indonesia
}

\begin{abstract}
This study assesses the gate-to-gate environmental impacts of food processing systems operating in Toba Samosir Regency using Life Cycle Assessment methodology. The systems in question are processing of tapioca, coffee, and tofu, with the functional units of $50 \mathrm{~kg}$ of tapioca starch, $1 \mathrm{~kg}$ of coffee powder, and $25 \mathrm{~kg}$ of tofu, respectively. The inventory data were collected directly from the producers in the form of both production records and interviews. The linked flows that describe the production process for each of the system are obtained as follow. In producing $50 \mathrm{~kg}$ of tapioca starch, $200 \mathrm{~kg}$ cassava root and $800 \mathrm{~kg}$ of water are required. This system generates $40 \mathrm{~kg}$ of cassava peel, $60 \mathrm{~kg}$ of pulp and discharges 850 $\mathrm{kg}$ of waste water. For starch drying $209 \mathrm{MJ}$ of thermal energy is required in the form of heating fuel. In order to produce $1 \mathrm{~kg}$ of fine coffee, $4 \mathrm{~kg}$ of coffee cherry and $30 \mathrm{~kg}$ of water are required. This system generates $3 \mathrm{~kg}$ of cherry peel and pulp mixture as solid co-product and discharges $30 \mathrm{~kg}$ of waste water. For roasting and milling the coffee bean, $90 \mathrm{MJ}$ of thermal energy is consumed from firewood and gasoline. In producing $25 \mathrm{~kg}$ of tofu, $11 \mathrm{~kg}$ of soybean, $0.2 \mathrm{~kg}$ of flour and $140 \mathrm{~kg}$ of water are required. This system generates $16 \mathrm{~kg}$ of wet pulp and discharges $89 \mathrm{~kg}$ of waste water. For milling, $250 \mathrm{MJ}$ of thermal energy is consumed from gasoline and rice husk. Water is the most vulnerable environmental compartment since most of the waste water is being discharged into the stream with limited treatment. The environmental hotspots associated with these systems are eutrophication potential, global warming potential (climate change), acidification, and photochemical oxidation potential.
\end{abstract}

Keywords: Life Cycle Assessment; Toba Samosir; tapioca; coffee; tofu.

\section{Introduction}

Lake Toba area is a natural ecosystem that provides strategic functions of the basic human needs and economic development. Recently, the Government of Indonesia is making every effort to accelerate the development of Lake Toba area, which includes the territory of Toba Samosir Regency, into a main tourist destination in the country. The development of Toba Samosir Regency has is also marked by the rise of industry sectors, particularly the agricultural/ food processing industry. There are many agricultural/ plantation products in Toba Samosir Regency such as cassava, coffee, beans, rice, etc. Some famous food industries in Toba Samosir Regency which utilize the agriculture / plantation products such as tapioca industry, coffee industry and tofu industry.

The food processing system, in its whole supply chain, is closely tied to material flows. In each supply chain, there will be processes that cause environmental impacts, from resource consumption to material emissions. The existence of various industries is closely related to the environmental sustainability that becomes the source of need and become the place of living things in doing the activity. In addition, Lake Toba Area is one of the key tourist areas in Indonesia. This area has become one of National Strategic Tourist Areas that the government focuses on for further development. According to Presidential Regulation no. 81 year 2014 on spatial plan of Lake Toba Area and surrounding areas, Lake Toba Area consists of 7 regencies, namely Simalungun Regency, Toba Samosir Regency, North Tapanuli Regency, Humbang Hasundutan Regency, Dairi Regency, Karo Regency and Samosir Regency [1].

Departing from this fact, the authors consider it important to conduct an assessment of the life cycle of the food processing systems in Toba Samosir Regency. This study aims to analyse mass balances and assess potential environmental impacts and provide recommendations for improvements to stakeholders which eventually provide pathway to make the transition toward the low carbon society.

\footnotetext{
*Corresponding author: yosef.manik@del.ac.id
} 


\section{Methodology}

Various tools and methods for assessing and benchmarking environmental impacts of different product system have been developed, ranging from the internationally standard Life Cycle Assessment/ LCA up to the contemporary integrated systems modelling framework for Life Cycle Sustainability Assessment/ LCSA $[2,3]$. In this study, we apply the Material Flow Analysis/ MFA technique, which is a life-cycle approach to analyse the flows and stock of a coherent group of substance in a flow model, as a tool in assessing the sustainability in particular the environmental impact.

\subsection{Goal and Scope}

The goal of this Material Flow Analysis (MFA) study is to assess the sustainability of food processing system through systematic analysis of energy and material flow in a "gate-to-gate" model. The inventory data were collected from primary data gathered from a tapioca starch industry, coffee industry and tofu industry located Toba Samosir Regency during the period between March and June 2018. The scope of this study covers all stages in the food processing systems ranging from raw material until finished products.

\subsection{Functional Unit}

The performance of food processing systems model are evaluated for the functional unit of one pack marketable tapioca starch weighs $50 \mathrm{~kg}, 1 \mathrm{~kg}$ of coffee powder and $25 \mathrm{~kg}$ of tofu.

\subsection{System Boundary}

The system boundary of food processing system models covers the entire unit processes (i.e., gate-to gate) that can be grouped as follow:

For Tapioca industry such as (1) sieving, (2) washing, (3) cutting, (4) rasping, (5) extraction, (6) separation, (7) peeling, (8) drying, (9) shifting, and (10) packaging (Fig. 1).

For Coffee Powder industry such as (1) sorting, (2) peeling the outer skin, (3) fermentation, (4) washing, (5) drying, (6) peeling skin deep, (7) sorting, (8) roasting, (9) milling (Fig. 2)

For Tofu industry such as (1) washing, (2) soaking, (3) milling, (4) filtering, (5) cooking, (6) Precipitation, (7) shaping (Fig. 3)

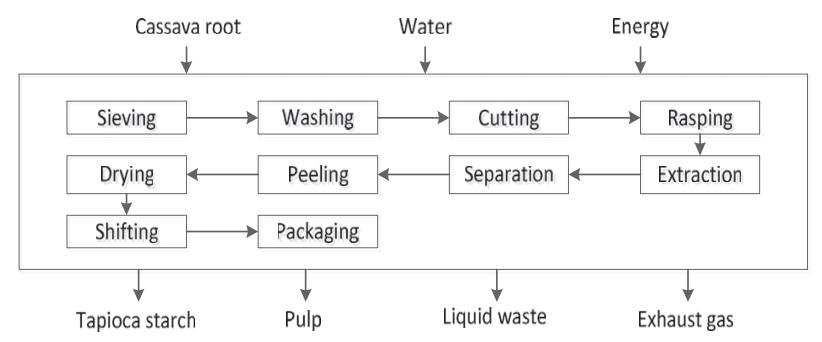

Fig. 1. System boundary of tapioca production system

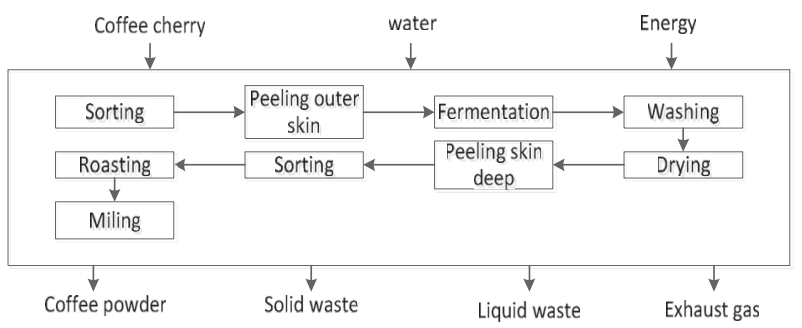

Fig. 2. System boundary of coffee powder production system

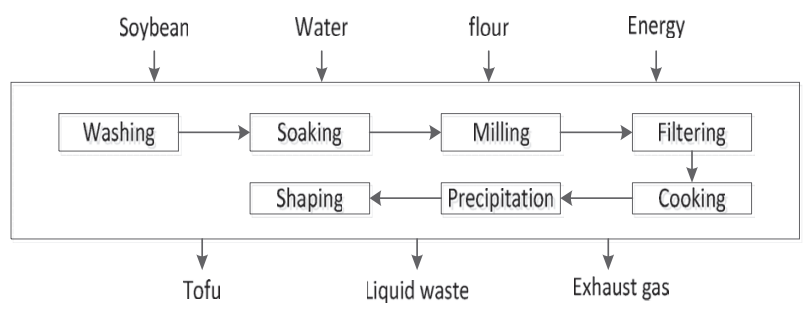

Fig 3. System boundary of tofu production system

\section{Data and Analysis}

\subsection{Tapioca Production: Life Cycle Inventory}

In this study, a comprehensive analysis was implemented covering all stages of tapioca starch production. The boundary of the system considered here includes the stages of the process directly related to the main product (tapioca starch). The flow model of the system is depicted in Fig 4. The following sections describe each step of the process from sieving to packaging.

Processing of raw materials begins from the process of difficulty to remove the layers of skin and dirt. Next stage is the washing stage to rinse the soil layer that is still attached to the cassava resulting from the difficulties. The results obtained from the washing of cassava that is clean to the skin and dirt soil attached which then proceeded to the cutting stage to minimize the size of cassava.

Small-sized cassava is then shredded to facilitate further extraction process. The dissolved cassava porridge is further extracted to separate starch with cassava dregs. Furthermore, the extracted starch is passed to the separation step to obtain viscous starch which will be converted to wet powder by peeler. Wet powder from dried peeler until dried flour yield. The drying process uses boiler with palm oil shell as much as $12 \mathrm{~kg}$. In fact, the process of burning the shell expels the soot which indicates an incomplete combustion. The exhaust gas can be $\mathrm{CO}, \mathrm{H}_{2}, \mathrm{~N}_{2}, \mathrm{CO}_{2}$ and $\mathrm{CH}_{4}$ [4,8]. Furthermore, the flour is dried, done sieving to get the desired level of refinement. At the end, smooth flour selected from shifter will be packed of $50 \mathrm{~kg}$ weight. The final product has the moisture content of $12 \%$ with quality standard in accordance with SNI 01-3451-1994.

Solid waste in the form of dregs is then used as animal feed and for cassava skin is dumped directly to the plantation land to be cassava compost.

The liquid waste generated from all stages of the process has the $\mathrm{BOD}$ and COD levels of around 5,000 
$\mathrm{mg} / \mathrm{l}$ and $10,000 \mathrm{mg} / \mathrm{l}$. This waste is then channelled into a waste treatment facility, which technically consists of 8 stages of settling ponds covers an area of $1.5 \mathrm{ha}$. After the sedimentation process, the BOD and COD of the liquid waste are turned into the levels $150 \mathrm{mg} / \mathrm{l}$ and $300 \mathrm{mg} / \mathrm{l}$, respectively [5].

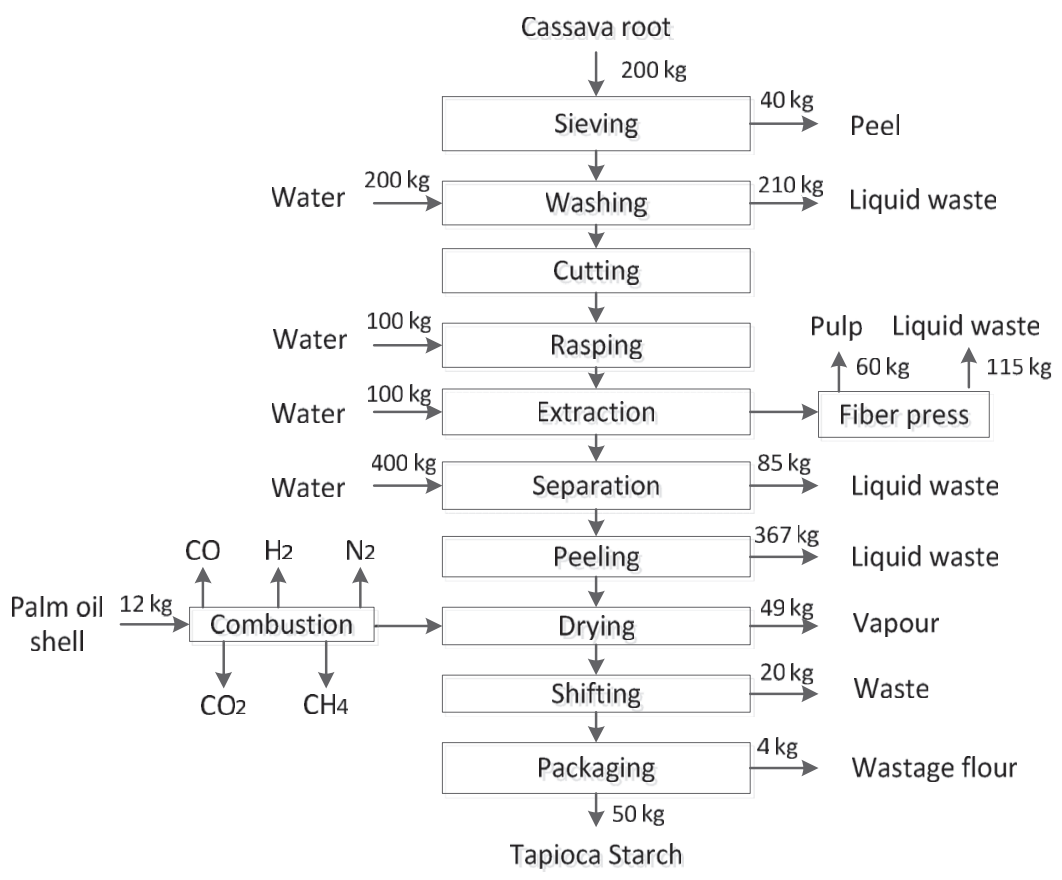

Fig. 4. Linked-flow of the tapioca production model

\subsection{Coffee Production: Life Cycle Inventory}

The boundary of the system considered here includes the stages of the process directly related to the main product (Coffee powder). The flow model of the system is depicted in Fig 5.

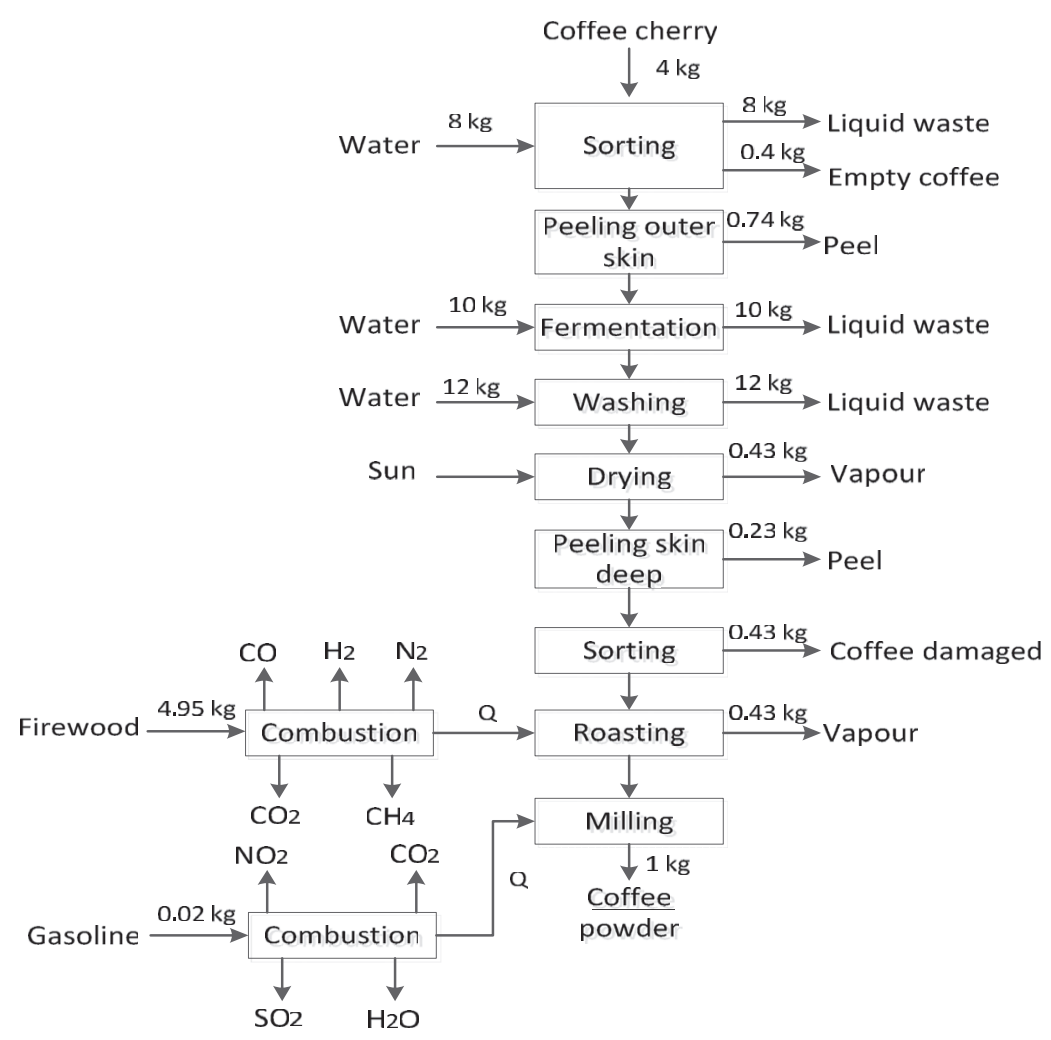

Fig. 5. Linked-flow of the coffee production model 
The following section describes each step of the process from sieving to packaging. The processing of coffee cherry begins with sorting to separate the good coffee (contains) with empty coffee. The sorting process is done by using water to determine floating seeds (empty seeds). Next good coffee peeled to remove skin I (outer skin). Deep coffee beans with soaked / fermented for 1 day to melt the mucus content in coffee beans. The fermentation process is carried out in a tub with a continuous flow of water (there are inlets and outlets).

Next the fermented coffee is washed back until the coffee is completely clean. The washed coffee beans are then dried in the sun to dry. After the coffee beans dried, then done deep stripping of the skin then re-sorting to separate the beans are really good coffee and coffee beans are rotten, broken and so forth. Good coffee is further roasted to reduce the water content evenly. Roasting is done at $150 \mathrm{C}-200{ }^{\circ} \mathrm{C}$ using firewood. In fact, the process of burning the firewood expels the soot which indicates an incomplete combustion. The exhaust gas can be $\mathrm{CO}$, $\mathrm{H}_{2}, \mathrm{~N}_{2}, \mathrm{CO}_{2}$ and $\mathrm{CH}_{4}$ [4]. The grinding process is done by using a milling machine with gasoline. In fact, the process of burning the gasoline does not cause soot which indicates a complete combustion. The exhaust gas can be $\mathrm{NO}_{2}, \mathrm{SO}_{2}, \mathrm{H}_{2} \mathrm{O}$ and $\mathrm{CO}_{2}$. The milling process results ground coffee ready for market. Solid waste in the form of skin and empty seeds are thrown directly into the garden as compost fertilizer. Liquid waste is discharged directly into the garden soil without going through the processing. Coffee liquid waste has a COD level of 628.56 $\mathrm{mg} / \mathrm{l}, \mathrm{BOD} 2.3 \mathrm{mg} / \mathrm{l}$ and $\mathrm{pH}$ of 5.1 [6].

\subsection{Tofu Production: Life Cycle Inventory}

The boundary of the system considered here includes the stages of the process directly related to the main product (tapioca starch). The flow model of the system is depicted in Fig 6.

The following section describes each step of the process from washing to shaping. The raw material in this production system is soybean that has no skin. The initial stage of processing is the washing of soy beans to remove the ashes attached to soybeans. Next soaked soybeans with water for 3-4 hours.

Soybean is then milled using a gasoline grinding machine. In fact, the process of burning the gasoline does not cause soot which indicates a complete combustion. The exhaust gas can be $\mathrm{NO}_{2}, \mathrm{SO}_{2}, \mathrm{H}_{2} \mathrm{O}$ and $\mathrm{CO}_{2}$. In the grinding process there is continuous addition of water to facilitate grinding. The output of the milling is a peanut porridge which will be taken away and separated the pulp. To take the starch content of the peanut porridge was filtered with the addition of warm water. Starch from the filtering results or soybean milk is cooked by using fuel that is rice husk. . In fact, the process of burning the rice husk expels the soot which indicates an incomplete combustion. The exhaust gas can be $\mathrm{CO}, \mathrm{H}_{2}, \mathrm{~N}_{2}, \mathrm{CO}_{2}$ and $\mathrm{CH}_{4}$ [4].

Cooked soybean milk is then precipitated to obtain a solid that will become tofu by adding a flour to help with the settling process. Deposition process is carried out for 1 hour until there is sediment. The next stage is the process of separation of water as well as shaping the tofu. In the shaping process, it is emphasized to solidify the precipitate to produce solid tofu. From the whole process, in addition to producing the main product, there is a solid waste of waste from the filtering process used as animal feed. Liquid waste from the entire production process is discharged / flowed directly to the field / land. Tofu liquid waste has a COD level of $6400 \mathrm{mg} / 1$, TSS $2800 \mathrm{mg} / 1$ and $\mathrm{pH}$ of 4.2 [7].

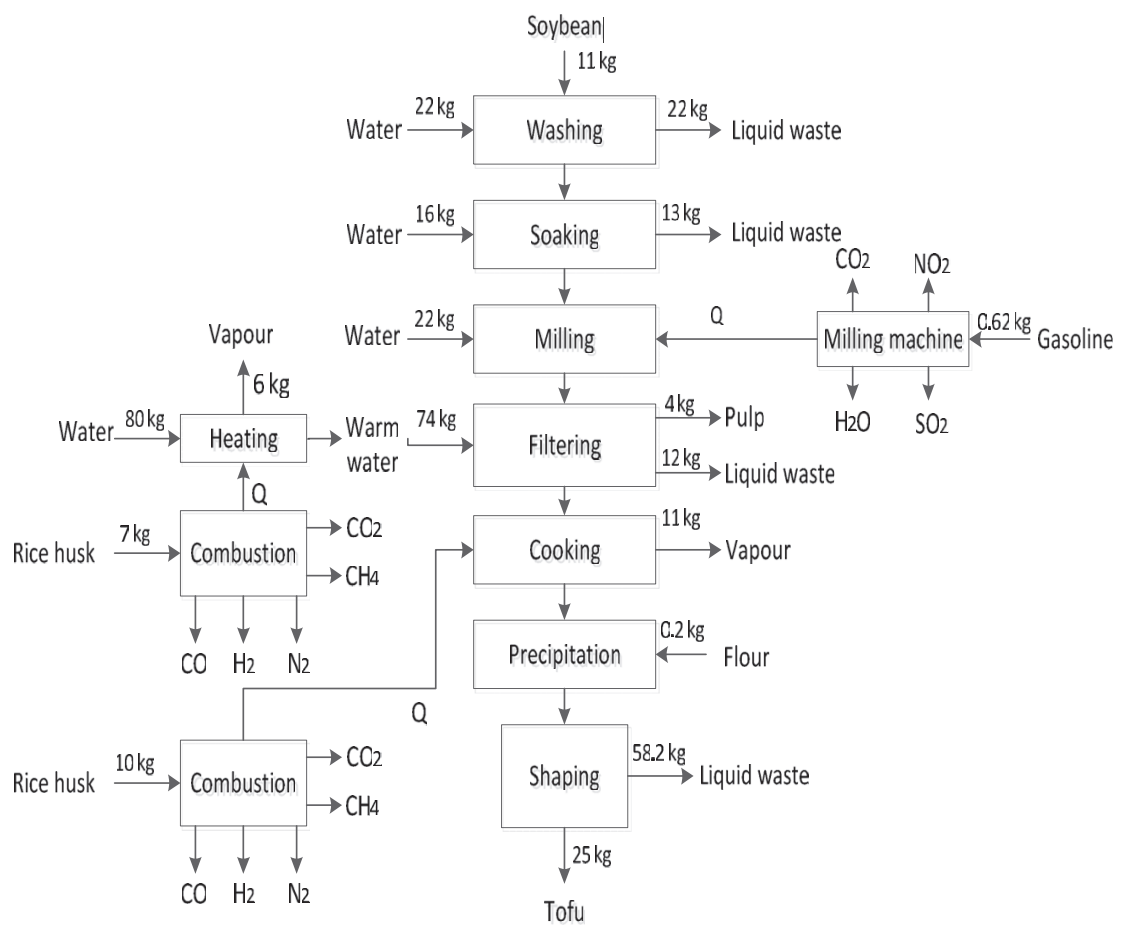

Fig. 6. Linked-flow of the tofu production model 


\section{Result and Discussion}

Based on the overall flow of material on the three production process analyzed through characterization based on [9], the potential environmental impacts associated with food production systems in questions are obtained and described as follow. The potential environmental impacts for producing $50 \mathrm{~kg}$ of tapioca are eutrophication (5.3844 $\mathrm{kg} \mathrm{PO}_{4}{ }^{3-}$ eq.), photo-oxidant ( $0.080285 \mathrm{~kg}$ ethane eq.) and climate change $\left(6.28 \mathrm{~kg} \mathrm{CO}_{2}\right.$ eq.). The potential environmental impacts for producing 1

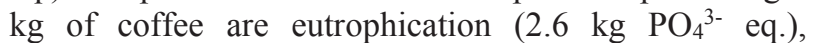
acidification ( $0.13 \mathrm{~kg} \mathrm{SO}$ eq.) photo-oxidant $(0.03 \mathrm{~kg}$ ethane eq.) and climate change (6.28 $\mathrm{kg} \mathrm{CO}_{2}$ eq.). The potential environmental impacts for producing $25 \mathrm{~kg}$ of tofu are eutrophication $\left(6.1 \mathrm{~kg} \mathrm{PO}_{4}{ }^{3-}\right.$ eq. $)$, acidification ( $0.005 \mathrm{~kg} \mathrm{SO}$ eq.) photo-oxidant (0.08 kg ethane eq.) and climate change (10.74 $\mathrm{kg} \mathrm{CO} 2$ eq.).

Based on impact analysis, it is understood that major potential environmental impacts of the food production systems in question are eutrophication, photo-oxidant, acidification, and climate change. Eutrophication, photooxidant, and acidification potentials occur as a result of discharging liquid waste to waterways without adequate waste water treatment. Climate change potential occurs as a result of carbon compound released through exhaust gases emissions, especially from the combustion of oil palm shell in tapioca production, firewood in coffee production, and rice husks in tofu production.

The remediation should, therefore, be focused in reducing potential impacts can be focused on handling liquid waste and exhaust gas. In terms of liquid waste, it is essential that all production center to develop waste water treatment system to reduce $\mathrm{COD}$ and $\mathrm{CH}_{4}$ levels through the deposition, filtration and activation of activated carbon before discharging them into the river which eventually empties to Lake Toba. As for the exhaust gas, it must be done by filtering the exhaust gas to reduce the level of carbon released into the air and increased planting trees that can reduce the level of $\mathrm{CO}_{2}$ in the air. In addition, replacing the old combustion system (incomplete combustion) into a new combustion system (complete combustion) where air will always be channeled in the combustion process is useful to minimize the impact of exhaust from the combustion process.

\section{Conclusion}

This research has successfully assessed the potential impact of production systems that exist in Toba Samosir Regency represented by three systems (i.e., tapioca, coffee, and tofu). In general, the environmental impacts that become hotspots of production systems in Toba Samosir are eutrophication, acidification, photo-oxidant and climate change. To reduce potential impacts can be focused on handling liquid waste and exhaust gas.
Reducing the carbon footprint throughout the production life cycle of each production system is essential in provide pathway to make the transition toward the low carbon society in Lake Toba area and in supporting the government policy in developing Lake Toba area as one of National Strategic Tourist Areas.

\section{Acknowledgment}

This research was funded by Indonesian Ministry of Research, Technology and Higher Education within grant scheme of International Collaborative Research Grant between Institut Teknologi Del and University of Queensland (Contract No. 022.9/ ITDel/ WRIII/ PKSLN/ IV/ 2018).

\section{References}

[1] Government of Indonesia, Peraturan Presiden tentang Rencana Tata Ruang Kawasan Danau Toba dan Sekitarnya. (Perpres No. 81/ 2014)

[2] International Standard Organization, Environmental management-Life cycle assessment-Principles and framework. (ISO 14040:2006)

[3] Halog, A. and Manik, Y. Life Cycle Sustainability Assessments. Book chapter in Encyclopedia of Inorganic and Bioinorganic Chemistry 1-17 (John Wiley \& Sons, 2016).

[4] Susanto, H. Utility System at Chemical Plant [in Bahasa Indonesia] (ITB Bandung, 2007)

[5] Situmorang, A dan Manik, Y. Initial Sustainability Assessment of Tapioca Starch Production in Lake Toba Area. IOP Conference Series: Materials Science and Engineering 337: 012044 (2018)

[6] Sutrisno. Improving the safety of liquid waste processing semi-wet seed coffee with anaerobic treatment [in Bahasa Indonesia]. Thesis. Universitas Jember (2011)

[7] Tuhu dan Winata. Tofu industry wastewater treatment using plasma technology [in Bahasa Indonesia]. Jurnal Ilmiah Teknik Lingkungan 2 (2) p. (2010)

[8] Kaválek, M., Havrland, B., Pecen, J., Ivanova, T., Hutla, P. Oil palm shell use as alternative biofuel. Agronomy Research 11 (1), pp. 183-188 (2013)

[9] Guine, J. Handbook on Life Cycle Assessment. Operational Guide to the ISO Standards. (Kluwer Academic Publisher, Amsterdam, 2002) 